\title{
Nutrient fluxes on an intertidal mudflat in Marennes-Oléron Bay, and influence of the emersion period
}

\author{
Michelle Feuillet-Girard, Dominique Gouleau, \\ Gérard Blanchard and Lucette Joassard
}

CNRS-IFREMER, Centre de Recherche en Écologie Marine et Aquaculture de I.Houmeau, BP 5, 17137 L'Houmeau, France.

Received March 27, 1996; accepted September 5, 1996.

Feuillet-Girard M., D. Gouleau, G. Blanchard, L. Joassard. Aquat. Living Resour., 1997, 10, 49-58.

\begin{abstract}
Fluxes of nutrients $\left(\mathrm{NH}_{4}^{+}, \mathrm{NO}_{3}^{-}, \mathrm{PO}_{4}^{3-}\right.$ and $\left.\mathrm{Si}(\mathrm{OH})_{4}\right)$ were studied on an intertidal mudflat in MarennesOléron Bay, France, at two different seasons and at different times of the emersion period. Fluxes through the sediment-water interface were both calculated from vertical profiles of nutrient concentration in porewater (diffusive fluxes, $\mathrm{J}_{\mathrm{D}}$ ) and measured in light and dark benthic mini-chambers (measured fluxes, $\mathbf{J}_{0}$ ). Results indicate that ammonia was mainly released in summer while nitrate was mainly taken up in late winter. This uptake from the overlying water was probably due to the coupling of nitrification-denitrification within the sediment. The $\mathrm{J}_{0} / \mathrm{J}_{\mathrm{D}}$ ratio further indicates that bioturbation likely enhanced ammonia release in summer. Concerning phosphate, the comparison of diffusive and measured fluxes suggests that $\mathrm{PO}_{1}^{3-}$ could be assimilated by the biofilm in winter while it was released in summer at a high rate due to both bioturbation and desorption because of the relative anoxic conditions in summer. Silica was always released by the sediment, but at a higher rate in summer. Statistically significant differences in measured fluxes were detected in dark chambers at different times of low tide, thus suggesting a short-term variability of fluxes. Microphytobenthos preferred ammonia to nitrate, but assimilated nitrate when ammonia was not available. It also turned out that benthic cells could be limited in nitrogen during low tide in late winter. In summer, ammonia was not limiting and microphytobenthic activity significantly decreased the measured flux of $\mathrm{NH}_{4}^{+}$in the middle of low tide when its photosynthetic capacity was highest.
\end{abstract}

Keywords: Intertidal mudflat, nutrient fluxes, microphytobenthos, bioturbation, Marennes-Oléron Bay.

Flux de nutriments sur un estran vaseux dans la baie de Marennes-Oléron et influence de l'exondation.

Résumé

La minéralisation des éléments nutritifs $\left(\mathrm{NH}_{4}^{+}, \mathrm{NO}_{3}^{-}, \mathrm{PO}_{4}^{3-}\right.$, and $\left.\mathrm{Si}(\mathrm{OH})_{4}\right)$ est étudiée sur un estran vaseux dans le bassin de Marennes-Oléron, France, à deux saisons différentes et à différents moments de la période d'exondation. Les flux qui ont leur siège à l'interface eau-sédiment ont été à la fois calculés à partir des profils verticaux des teneurs en sels nutritifs dans les eaux interstitielles (flux diffusifs; $J_{D}$ ) et mesurés dans des mini-enceintes claires et opaques (flux mesurés; $\mathrm{J}_{0}$ ), placées sur la vasière. Ainsi l'ammonium est principalement relâché en été, les nitrates sont essentiellement absorbés par le sédiment à la fin de l'hiver. Cette absorption est probablement due à un couplage des processus de nitrification-dénitrification dans le sédiment. Le rapport $\mathrm{J}_{0} / \mathrm{J}_{\mathrm{D}}$ indique que la libération d'ammonium a probablement été accrue par la bioturbation. Les phosphates sous forme d'ions $\mathrm{PO}_{4}^{3-}$ seraient assimilés par le biofilm en hiver alors qu'ils ont été relâchés dans l'eau à un fort taux en été, dû à l'action conjuguée de la bioturbation et de la désorption consécutive aux conditions d'anoxie relative en été. La silice présente toujours des flux dirigés du sédiment vers la colonne d'eau, avec une intensité plus forte en été. Des différences statistiquement significatives ont été décelées dans les enceintes opaques au cours de l'exondation, suggérant ainsi l'existence d'une variabilité à l'échelle horaire. Les résultats montrent également que le microphytobenthos a une forte 
affinité pour l'ammonium, bien qu'il assimile les nitrates en l'absence d'ammonium. Il s'est aussi avéré que les cellules algales benthiques pouvaient être potentiellement limitées en azote pendant la marée basse en hiver. En été, l'ammonium n'est pas un facteur limitant et l'activité microphytobenhique entraîne une baisse des flux d'ammonium à marée basse lorsque la photosynthèse est la plus forte.

Mots-clés : Estran vaseux, flux de nutriments, microphytobenthos, bioturbation, Marennes-Oléron.

\section{INTRODUCTION}

Primary production of phytoplankton in coastal areas is directly dependent upon the nutrient supply, in which benthic regeneration can represent an important contribution (Boynton et al., 1980; Nixon, 1981; Callender and Hammond, 1982; Hopkinson, 1987). Nutrient fluxes at the sediment-water interface can indeed influence or regulate the nutrient composition of the water column since the sediment can behave as a sink or as a source of inorganic nitrogen, phosphorus and silica through different biogeochemical processes (Nixon et al., 1976; Billen, 1978; Peterson, 1979; Kemp et al., 1990). Moreover, in the most shallow waters, where a sufficient amount of light reaches the sediment surface, microphytobenthos photosynthesis is also tightly coupled to fluxes of dissolved inorganic nutrients through the sedimentwater interface (Nowicki and Nixon, 1985; Rizzo, 1990; Nilsson et al., 1991; Sundbäck et al., 1991; Rizzo et al., 1992; Riera and Richard, 1996) so that the autotrophic activity of the sediment has to be taken into account if a total understanding of the cycling of matter in coastal areas is to be achieved.

A large part of Marennes-Oléron Bay is composed of intertidal mudflats where exchanges of nutrients between the sediment and the overlying water only occur during high tide whereas the sediment is exposed to the air at low tide. During this period, the physical state of the mudflat surface changes due to drainage and evaporation. However, the influence of emersion on organic matter mineralization and nutrient fluxes, either directly or indirectly through a modification of the global biological activity, is still unknown. The aim of the present paper therefore was not only to study the general pattern of nutrient flux in Marennes-Oléron Bay, but also to assess the influence of the emersion period and the biological activity on the potential fluxes of nutrients during low tide. To achicve this goal, nutrient fluxes were measured in two contrasting situations (in late winter and in summer), and at different times of a single low tide. It has been assumed that fluxes measured at the beginning of low tide were still representative of fluxes of the preceding high tide, whereas fluxes measured later during low tide were supposed to reflect changes in the biogeochemical processes occurring during emersion. Calculation of diffusive fluxes was based on the difference between nutrient concentration in pore-water and in the water column of the preceding high tide. Measured fluxes were measured using benthic mini-chambers filled with water obtained at the end of the preceding high tide. In addition, dark and light chambers were used to point out the effect of microphytobenthos photosynthesis on fluxes. These two different methods for estimating fluxes (diffusive vs. measured fluxes) have been used because they usually differ and the analysis of the measured flux/diffusive flux ratio can provide information on the biological and chemical processes involved in the dynamics of these fluxes.

\section{MATERIAL AND METHODS}

\section{Sampling}

All measurements were performed at a high-level station on a mudflat (in the eastern part of MarennesOléron Bay, France; Fig. 1) at low tide during spring tide periods, in late winter (19 March 1992; mud temperature between 10 and $18^{\circ} \mathrm{C}$ during low tide) and in summer (30 July 1992; mud temperature between 23 and $28^{\circ} \mathrm{C}$ during low tide), and at different times of the emersion period: at the beginning (T0), in the middle (T3) and at the end (T6).

\section{Calculation of diffusive fluxes}

Triplicate cores $\left(68 \mathrm{~cm}^{2}\right)$ were sampled at each sampling time and date, using PVC tubes. Cores were immediately sectioned: $0-0.5,0.5-1 \mathrm{~cm}$, and every $\mathrm{cm}$ down to $5 \mathrm{~cm}$ depth. Each section was divided in two sub-samples. The first one was used to measure nutrient concentration $\left(\mathrm{NH}_{4}^{+}, \mathrm{NO}_{3}^{-}, \mathrm{PO}_{4}^{3-}\right.$ and $\left.\mathrm{Si}(\mathrm{OH})_{4}\right)$ in pore water after centrifugation $(2,000 \mathrm{~g}$ during $10 \mathrm{~min}$ ) and filtration through Whatman GF/F; the second was used to determine sediment porosity after drying at $60^{\circ} \mathrm{C}$ during $48 \mathrm{~h}$.

Diffusive flux calculation was made using the following formulation (Berner, 1976):

$$
\mathrm{J}_{\mathrm{D}}=-\varphi \mathrm{D}_{\mathrm{S}} \delta \mathrm{C}_{i} / \delta \mathrm{x}
$$

where $J_{D}$ is the diffusive flux $\left(\mu \mathrm{mol} \cdot \mathrm{m}^{-2} \cdot \mathrm{h}^{-1}\right), \varphi$ is the sediment porosity expressed as a percentage, $\delta \mathrm{C}_{\mathrm{i}} / \delta \mathrm{x}$ is the concentration gradient of $\mathrm{NH}_{4}^{+}, \mathrm{NO}_{3}^{-}, \mathrm{PO}_{4}^{3-}$ or $\mathrm{Si}(\mathrm{OH})_{4}\left(\mu \mathrm{mol} \cdot \mathrm{J}^{-1} \cdot \mathrm{cm}^{-1}\right)$, and $\mathrm{DS}_{\mathrm{S}}$ the whole sediment diffusion coefficient $\left(\mathrm{cm}^{2} . \mathrm{s}^{-1}\right)$ expressed by Krom and Berner (1980) as:

$$
\mathrm{D}_{\mathrm{s}}=\mathrm{D}_{0} / \varphi_{0} \mathrm{~F}^{\prime}
$$

where $\mathrm{D}_{0}$ is the diffusion coefficient for $\mathrm{NH}_{4}^{+}, \mathrm{NO}_{3}^{-}$, $\mathrm{PO}_{4}^{3-}$ or $\mathrm{Si}(\mathrm{OH})_{4}$ in water at infinite dilution $(\mathrm{Li}$ and 


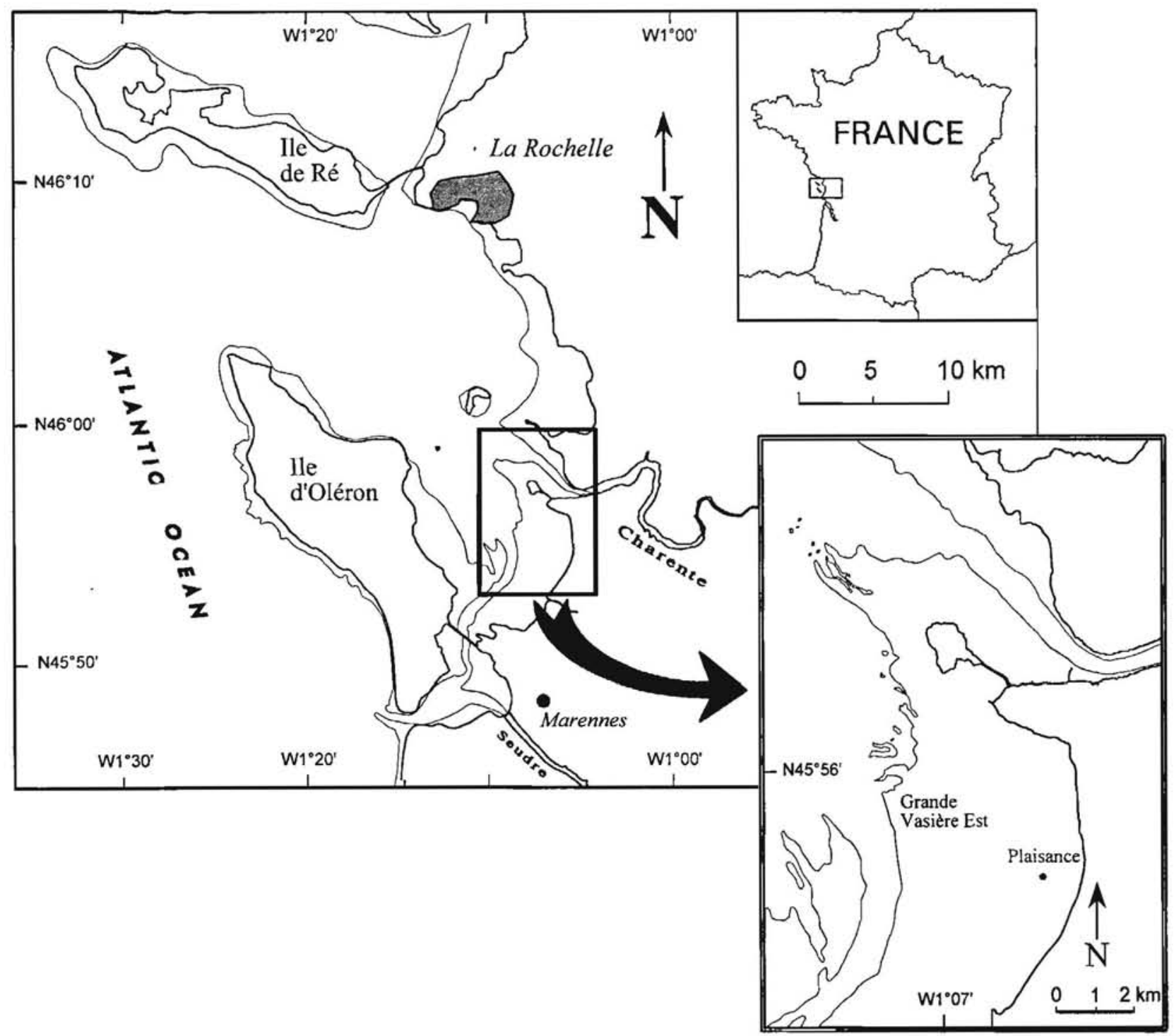

Figure 1. - Location of the study site " Plaisance " on the " Grande Vasière Est " in the Bay of Marennes-Oléron along the French Atlantic coast.

Gregory, 1974) and $\mathrm{F}^{\prime}$ is the modified formation factor of Krom and Berner (1980) corrected for viscosity and deviation from the Archie's relation $\left(\mathrm{F}=\varphi_{0}^{-2}\right.$; Manhein, 1970),

$$
\mathrm{F}^{\prime}=1.28 \varphi_{0}^{-\mathrm{m}}
$$

with

$$
\mathrm{m}=2 \text { if } \varphi_{0}<0.7
$$

or

$$
m=3 \text { if } \quad \varphi_{0}>0.7
$$

where $\varphi_{0}$ is the average sediment porosity.

Values for $\mathrm{D}_{0}$ were taken from $\mathrm{Li}$ and Gregory (1974) corrected for changes in temperature by using the Stokes-Einstein relation. $\delta \mathrm{C}_{i}$ is the difference between nutrient concentration of the interface and the concentration in the water column, and $\delta \mathrm{x}$ is $0.5 \mathrm{~cm}$ because it cannot be assumed that the fluxes from the sediment into the water column can be estimated by extending the concentration gradients from several $\mathrm{cm}$ depth in the sediment through the interface (Simon, 1988).

\section{Measured fluxes}

Exchanges of inorganic nutrients across the sediment-water interface were estimated by measuring changes of their respective concentrations as a function of time in a water volume contained within light and dark chambers $\left(\right.$ volume $=0.31 ;$ covered area $=40 \mathrm{~cm}^{2}$ ). Mini-incubators were used to allow replication and 
to take into account the natural heterogeneity of the sediment. In practice, mini-chambers were pushed into the sediment down to a depth of $3 \mathrm{~cm}$. They were then filled with incubation water, without creating air bubbles and limiting as much as possible sediment resuspension, by means of a $300 \mathrm{ml}$-syringe. At the end of incubation, water was withdrawn for nutrient measurement after filtration $\mathrm{NH}_{4}^{+}, \mathrm{NO}_{3}^{-}, \mathrm{P(O}_{4}^{3-}$ or $\mathrm{Si}(\mathrm{OH})_{4}$ were measured with a Skalar autoanalyser.

\section{Sampling strategy}

Three successive and independent incubations during low tide were performed (see Fig. 2 for details). Each incubation lasted 3 hours: 9 dark and 9 light mini-incubators were randomly deployed onto the surface of the sediment and 6 of them ( 3 dark and 3 light) were removed every hours (1, 2, and 3 hours after the beginning of incubations) to determine the concentration of the different chemical species. There was a partial overlap between the successive incubations (Fig. 2). In March, there were only 2 successive incubations for light chambers, without overlap. All measurements were independent (from
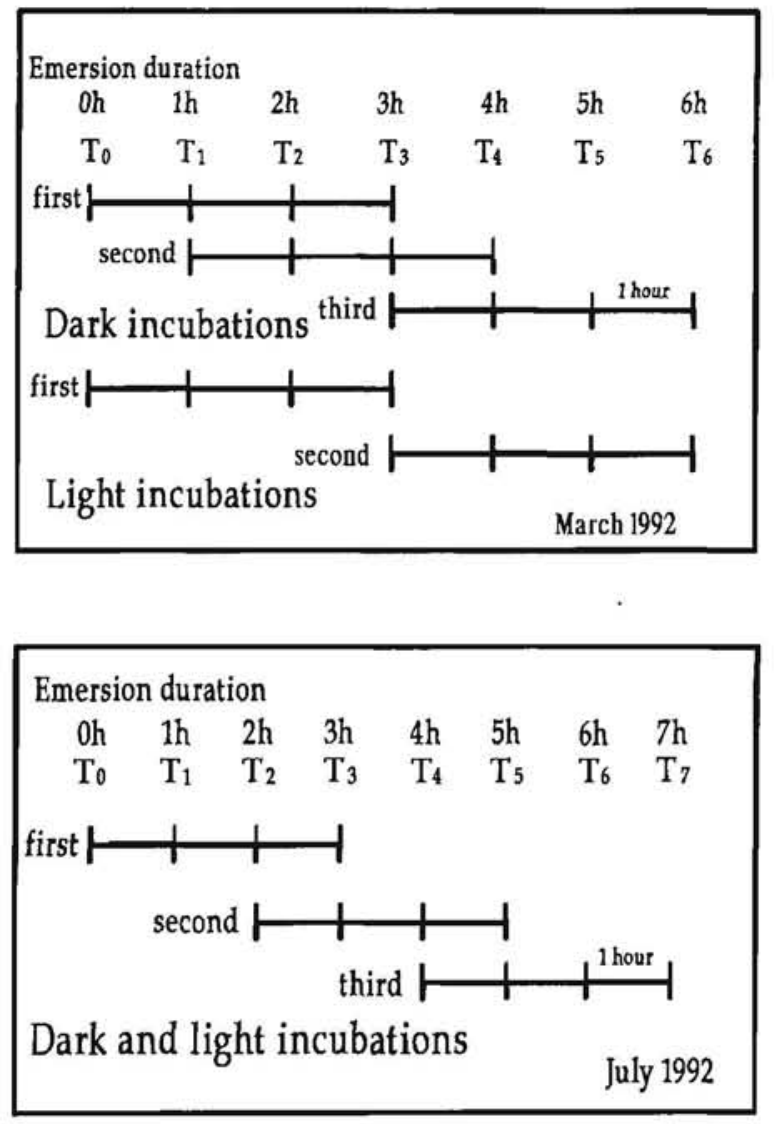

Figure 2. - Emersion duration for March and July 1992 surveys, and denomination of different incubations during the low tide with dark or light mini-incubators. individual chambers), thus allowing a true replication and a statistical analysis of the results. Based on these independent replicates, determination of the fluxes $\mathrm{J}_{0}$ (directed to or from the sediment as a function of an uptake or a release of dissolved material) relative to the incubation period were based on the slope of regression equations (change in concentration as a function of time). Agreement of observed distributions with the normal distribution was previously checked by the Kolmogorov-Smirnov and Lillicfors' tests (Sokal and Rohlf, 1981). Whenever slopes were to be compared, a covariance analysis was employed.

\section{RESULTS}

\section{Diffusive fluxes}

Nutrient profiles in the sediment obtained at different times during low tide in March and July 1992 are presented in Figure 3 as well as the nutrient concentrations in the overlying water just before the emersion; they have been used to calculate the diffusive fluxes $\left(J_{D}\right.$; Table 1$)$. Profiles were homogeneous for ammonia and silica but they were variable for nitrate and phosphate (Fig. 3). As each profile was the mean of 3 cores, it indicates that nutrient pore water concentration can fluctuate at a short time scale, but a clear pattern of variation could not be detected from those measurements. Ammonia, phosphate and silica concentrations at the surfacc of the sediment (top $0.5 \mathrm{~cm}$ ) were higher than in the overlying water both in late winter and in summer, but the opposite was observed for nitrate.

Diffusive fluxes for $\mathrm{NH}_{4}^{+}$, calculated from pore water profiles, from the sediment to the overlying water were in the range $26.4-38.3 \mu \mathrm{mol} \cdot \mathrm{m}^{-2} \cdot \mathrm{h}^{-1}$ in March but they were more than twice as high in summer $\left(\mathrm{ca}\right.$. 60.3-104.8 $\mu \mathrm{mol} \cdot \mathrm{m}^{-2} \cdot \mathrm{h}^{-1}$; Table 1). Concerning the uptake of nitrate by the sediment it was higher in winter $\left(c a .8 .0-22.1 \mu \mathrm{mol} \cdot \mathrm{m}^{-2} \cdot \mathrm{h}^{-1}\right)$ than in summer $\left(\mathrm{ca}\right.$. 3.4-5.7 $\left.\mu \mathrm{mol} \cdot \mathrm{m}^{-2} \cdot \mathrm{h}^{-1}\right)$. The release of phosphate from the sediment was low and was similar in March and in July (0.4-1.1 and 0.6$1.2 \mu \mathrm{mol} \cdot \mathrm{m}^{-2} \cdot \mathrm{h}^{-1}$, respectively). In March the silica fluxes ranged from 4.4 at the beginning to 5.6 $\mu \mathrm{mol} \cdot \mathrm{m}^{-2} \cdot \mathrm{h}^{-1}$ at the end of the emersion with a low level observed in the middle of it. In July the silica fluxes were about 5 to 7 times higher than in winter, but presented a similar behaviour.

\section{Measured fluxes in benthic mini-chambers}

Measurements of fluxes through the sediment-water interface (reconstituted at low tide for the purpose of the present study) using dark benthic chambers exhibited the same general trend as diffusive fluxes in terms of uptake and release by the sediment (except for phosphate in March where the results were opposite). 


\section{NUTRIEITT PORE WATER COIVCENTRATION ( $\mu$ IVi)}

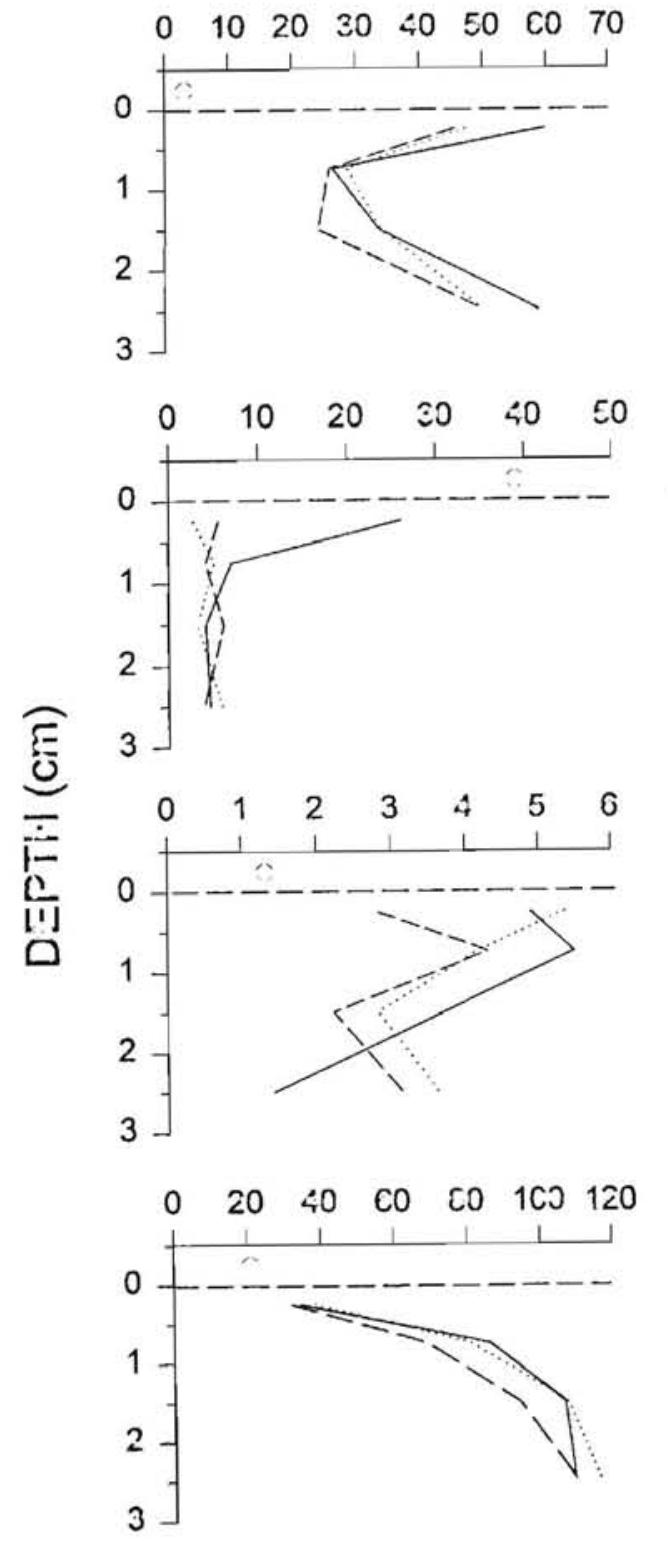

19 inarcil 1982
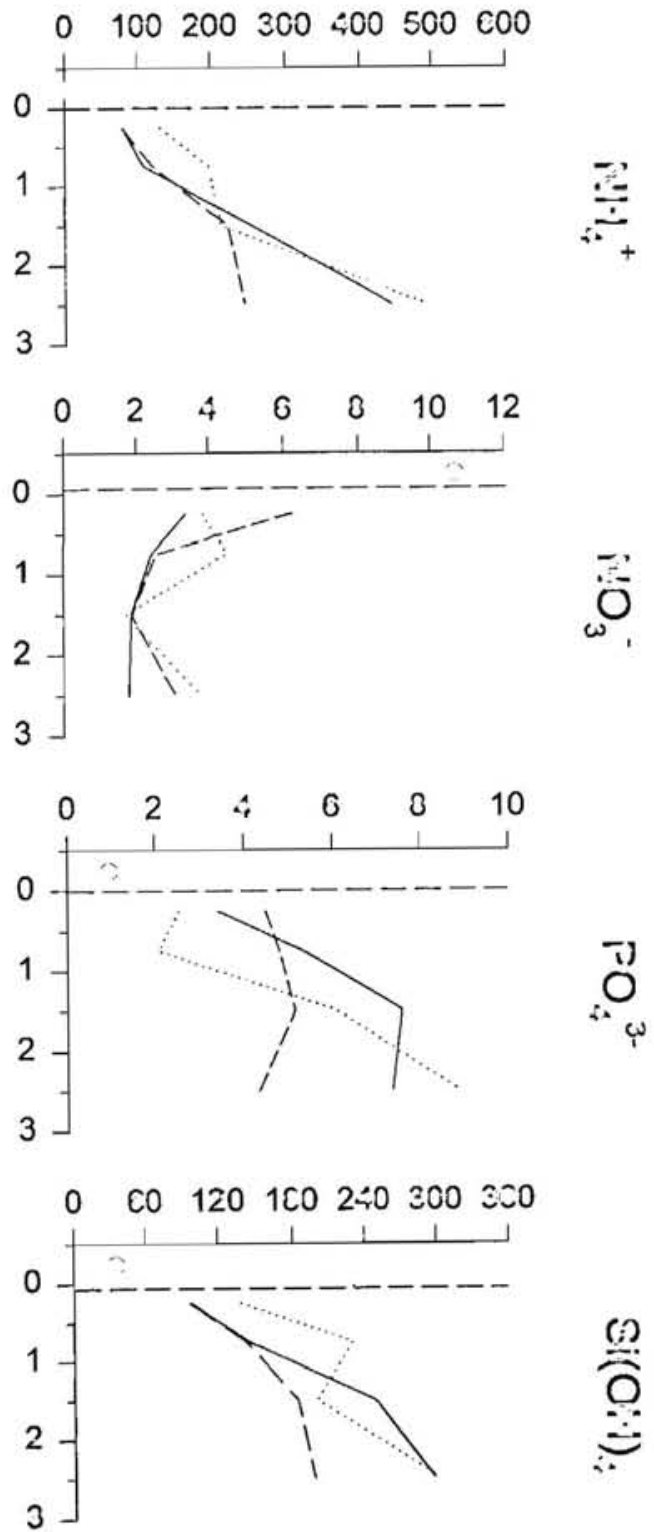

30 July 1092

Thizir 3. - Nitrient pore water concertration (mM) as a function of depth $(0-3 \mathrm{~cm})$ for $\mathrm{NH}_{4}^{+}, \mathrm{NO}_{3}^{-}, \mathrm{PO}_{4}^{3-}$ and $\mathrm{Si}(\mathrm{OH})_{4}$ on $19 \mathrm{March}$ and 30 Jily 1992. The horizor:al das..ed line insicaties the secimert-water interface. Vertical profiles at T0 (solid line), at T3 (dashed line) and at T6 (Co:sed line) are preserted as well as the retrient concertration in the overlying water of the preceding high tide (full circle).

liseasured fiuxes for ammonium were lower than diffusive fuxes and did not exceed $11.7 \mu \mathrm{mol} \cdot \mathrm{m}^{-2} \cdot \mathrm{h}^{-1}$ in March, whereas in July they reached 209.4 $\mu \mathrm{mol} \cdot \mathrm{m}^{-2} \cdot \mathrm{h}^{-1}$ and were ligher than diffusive fluxes (Table 1). IJitrate was about 3 times higher in March then in July. For silica, fuxes were 5 to 10 times higher in July than in March with a drop at the end of the emersion in both cases. In March, phosphate fluxes measured in benthic mini-chambers showed an uptake by the sediment (about $5 \mu \mathrm{mol} \cdot \mathrm{m}^{-2} \cdot \mathrm{h}^{-1}$, Table 1 ), whereas there was a release in July (fluxes reached $\left.27 \mu \mathrm{mol} \cdot \mathrm{m}^{-2} \cdot \mathrm{h}^{-1}\right)$. 
Table 1. - Diffusive fluxes $\left(\mathrm{J}_{\mathrm{D}}\right)$ and measured fluxes $\left(\mathrm{J}_{0}\right)$ of $\mathrm{NH}_{4}^{+}$, $\left.\mathrm{N}_{3}^{-}, \mathrm{PO}\right)_{4}^{3-}$ and $\mathrm{Si}(\mathrm{OH})_{4}$ at different times of the emersion period (T0 to T3, T1 to T4, and T3 to T6) on 19 March and 30 July 1992. $\mathrm{J}_{6} / \mathrm{J}_{\mathrm{D}}$ is the measured to diffusive flux ratio and $\mathrm{SE}$ is the standard error. NS: non statistically significant fluxcs.

\begin{tabular}{|c|c|c|c|c|}
\hline Incubation & $\mathrm{J}_{\mathrm{D}} \pm \mathrm{SE}$ & $\mathrm{J}_{0} \pm \mathrm{SE} \quad \mathrm{J}$ & $\mathrm{J}_{0} / \mathrm{J}_{\mathrm{D}}$ & \\
\hline \multicolumn{5}{|c|}{19 March 1992} \\
\hline $\mathrm{NH}_{4}^{+}$ & $\begin{array}{l}\mathrm{T} 0 \text { to } \mathrm{T} 3 \\
\mathrm{~T} 1 \text { to } \mathrm{T} 4 \\
\mathrm{~T} 3 \text { to } \mathrm{T} 6\end{array}$ & $\begin{array}{l}38.3 \pm 14.8 \\
26.4 \pm 10.3 \\
28.3 \pm 2.6\end{array}$ & $\begin{array}{c}11.7 \pm 3.7 \\
\text { NS } \\
\text { NS }\end{array}$ & 0.30 \\
\hline $\mathrm{NO}_{3}^{-}$ & $\begin{array}{l}\mathrm{T} 0 \text { to } \mathrm{T} 3 \\
\mathrm{~T} 1 \text { to } \mathrm{T} 4 \\
\mathrm{~T} 3 \text { to } \mathrm{T} 6\end{array}$ & $\begin{array}{l}-\quad 8.0 \pm 0.5 \\
-19.9 \pm 1.8 \\
-22.1 \pm 0.8\end{array}$ & $\begin{array}{l}-109.5 \pm 15.3 \\
-100.7 \pm 13.8 \\
-159.8 \pm 18.2\end{array}$ & $\begin{array}{r}13.68 \\
5.06 \\
7.22\end{array}$ \\
\hline $\mathrm{PO}_{1}^{3-}$ & $\begin{array}{l}\mathrm{T} 0 \text { to } \mathrm{T} 3 \\
\mathrm{~T} 1 \text { to } \mathrm{T} 4 \\
\mathrm{~T} 1 \text { to } \mathrm{T} 4\end{array}$ & $\begin{array}{l}1.0 \pm 0.1 \\
0.4 \pm 0.1 \\
1.1 \pm 0.5\end{array}$ & $\begin{array}{l}-5.3 \pm 1.0 \\
-\quad 2.7 \pm 1.2 \\
-\quad 5.0 \pm 1.7\end{array}$ & $\begin{array}{l}- \\
-\end{array}$ \\
\hline $\mathrm{Si}(\mathrm{OH})_{4}$ & $\begin{array}{l}\mathrm{T} 0 \text { to } \mathrm{T} 3 \\
\mathrm{~T} 1 \text { to } \mathrm{T} 4 \\
\mathrm{~T} 1 \text { to } \mathrm{T} 4\end{array}$ & $\begin{array}{l}4.4 \pm 0.3 \\
3.4 \pm 0.6 \\
5.6 \pm 2.6\end{array}$ & $\begin{array}{c}94.9 \pm 31.3 \\
49.1 \pm 13.9 \\
\text { NS }\end{array}$ & $\begin{array}{l}21.71 \\
14.66 \\
-\end{array}$ \\
\hline \multicolumn{5}{|c|}{30 July 1992} \\
\hline $\mathrm{NH}_{4}^{+}$ & $\begin{array}{l}\mathrm{T} 0 \text { to } \mathrm{T} 3 \\
\mathrm{~T} 2 \text { to } \mathrm{T} 5 \\
\mathrm{~T} 4 \text { to } \mathrm{T} 7\end{array}$ & $\begin{array}{r}61.2 \pm 9.4 \\
60.3 \pm 16.7 \\
104.8 \pm 19.2\end{array}$ & $\begin{array}{l}209.4 \pm 19.9 \\
178.8 \pm 46.0 \\
178.8 \pm 28.5\end{array}$ & $\begin{array}{l}3.42 \\
2.96 \\
1.71\end{array}$ \\
\hline $\mathrm{NO}_{3}^{-}$ & $\begin{array}{l}\mathrm{T} 0 \text { to } \mathrm{T} 3 \\
\mathrm{~T} 2 \text { to } \mathrm{T} 5 \\
\mathrm{~T} 4 \text { to } \mathrm{T} 7\end{array}$ & $\begin{array}{l}-\quad 5.7 \pm 0.89 \\
-\quad 3.4 \pm 1.38 \\
-\quad 3.4 \pm 0.52\end{array}$ & $\begin{array}{l}-37.9 \pm 5.0 \\
-34.34 \pm 5.8 \\
-\end{array}$ & $\begin{array}{r}6.66 \\
10.06 \\
-\end{array}$ \\
\hline $\mathrm{PO}_{4}^{3-}$ & $\begin{array}{l}\text { T0 to T3 } \\
\text { T2 to T5 } \\
\text { T4 to T7 }\end{array}$ & $\begin{array}{l}0.9 \pm 0.3 \\
1.2 \pm 0.1 \\
0.6 \pm 0.1\end{array}$ & $\begin{array}{l}26.3 \pm 2.8 \\
20.7 \pm 4.0 \\
27.0 \pm 2.9\end{array}$ & $\begin{array}{l}30.99 \\
17.12 \\
48.14\end{array}$ \\
\hline $\mathrm{Si}(\mathrm{OH})_{4}$ & $\begin{array}{l}\text { T0 to T3 } \\
\text { T2 to T5 } \\
\text { T4 to T7 }\end{array}$ & $\begin{array}{l}25.5 \pm 6.1 \\
24.7 \pm 1.3 \\
42.5 \pm 6.7\end{array}$ & $\begin{array}{l}529.8 \pm 66.4 \\
402.0 \pm 136.4 \\
345.1 \pm 94.6\end{array}$ & $\begin{array}{r}20.77 \\
16.26 \\
8.13\end{array}$ \\
\hline
\end{tabular}

\section{Ratio $\mathbf{J}_{0} / \mathbf{J}_{\mathrm{D}}$}

In March the ratio of measured to diffusive fluxes $\left(\mathrm{J}_{0} / \mathrm{J}_{\mathrm{D}}\right)$ of ammonia was lower than unity $(0.30$, Table 1), but higher than unity in July (1.71-3.42). For phosphate in March, the ratio was not calculated because measured and diffusive fluxes were opposite. In all other cases, the ratio was much higher than unity (Table 1).

\section{Hourly variability of measured fluxes in dark and light mini-chambers}

There were differences between fluxes measured at different times of the emersion periods in dark chambers as well as in light chambers. Moreover, there were differences between light and dark measurements, thus showing the nutrient assimilation by microphytobenthos (Fig. 4). Concerning nitrogen fluxes, there was a low but significant flux of $\mathrm{NH}_{4}^{+}$ in dark chambers at the beginning of the emersion period in March $\left(11.7 \mu \mathrm{mol} \cdot \mathrm{m}^{-2} \cdot \mathrm{h}^{-1}\right)$, then no flux could be detected. On the contrary, significant uptakes of ammonia were measured in light chambers with higher fluxes in the second part of low tide in March (about 35 and $57 \mu \mathrm{mol} \cdot \mathrm{m}^{-2} \cdot \mathrm{h}^{-1}$, respectively).
Nitrate uptake in dark chambers was significantly higher at the end of emersion $(p<0.05)$, and nitrate uptakes were significantly higher $(p<0.05)$ in light than in dark mini-chambers. It turned out that when photosynthesis of microphytobenthos occurred, nitrate uptake rate was about 2 -fold higher (100-160 vs. about $\left.260 \mu \mathrm{mol} \cdot \mathrm{m}^{-2} \cdot \mathrm{h}^{-1}\right)$. In July, there was no difference in nitrate uptake between light and dark chambers but there was a significantly lower release of ammonia in the middle of low tide in light chambers $(p<0.05)$.

\section{DISCUSSION}

\section{General pattern of nutrient fluxes in Marennes- Oléron Bay}

There seemed always to be a release of ammonia and an uptake of nitrate by the sediment: as predicted by nutrient gradients, nitrate was mainly taken up in late winter and ammonia released in summer, which is consistent with previous observations (Feuillet-Girard et al., 1988; Kemp et al., 1990). There was always a release of silica, but diffusive fluxes were 5 to 10 times higher in July $\left(25-43 \mu \mathrm{mol} \cdot \mathrm{m}^{-2} \cdot \mathrm{h}^{-1}\right)$ than in March (3-5 $\left.\mu \mathrm{mol} \cdot \mathrm{m}^{-2} \cdot \mathrm{h}^{-1}\right)$, probably because of the temperature increase from about $15^{\circ} \mathrm{C}$ to about $25^{\circ} \mathrm{C}$.

In March, the low ratio $\left(\mathrm{J}_{0} / \mathrm{J}_{\mathrm{D}}\right)$ of ammonia suggested a probable sink of $\mathrm{NH}_{4}^{+}$. In the meantime, the measured uptake rates of nitrate $\left(J_{0}\right)$ suggest that ammonia could be lost by nitrification (Williams et al., 1985), and possibly nitrate uptake could be due to denitrification or dissimilatory $\mathrm{NO}_{3}^{-}$ reduction in the underlying reduced zone or within reduced microenvironnements (Lerat et al., 1990). As denitrification is frequently limited by the availability of nitrate in coastal environments (Koike and Sorensen, 1988), there could have been a coupling of nitrification and denitrification (Seitzinger, 1988; Jenkins and Kemp, 1984). This probably occurred at our study site since parallel measurements indicate that both nitrification and denitrification rates were high at this site in winter (Feuillet-Girard et al., unpublished).

Contrary to the diffusive net release of phosphate by the sediment (around $1 \mu \mathrm{mol} \cdot \mathrm{m}^{-2} \cdot \mathrm{h}^{-1}$ ), the measurements performed within the benthic minichambers showed an uptake by the sediment (about $5 \mu \mathrm{mol} \cdot \mathrm{m}^{-2} \cdot \mathrm{h}^{-1}$; Table 1). This inverse flux from low (overlying water) to high (pore water) concentrations was not a diffusional process and could be due very likely to phosphate assimilation from the overlying water by the biofilm (benthic microalgae and associated bacteria) present at the sediment-water interface.

The $J_{0} / J_{D}$ ratio for silica was in the range $15-20$ in March (except at the end of the emersion period where the measured flux was not statistically significant (Table 1). This enhancement of fluxes, compared to those based on molecular diffusion, could be likely due to bioturbation (Rutgers van der Loeff et al., 1984), 


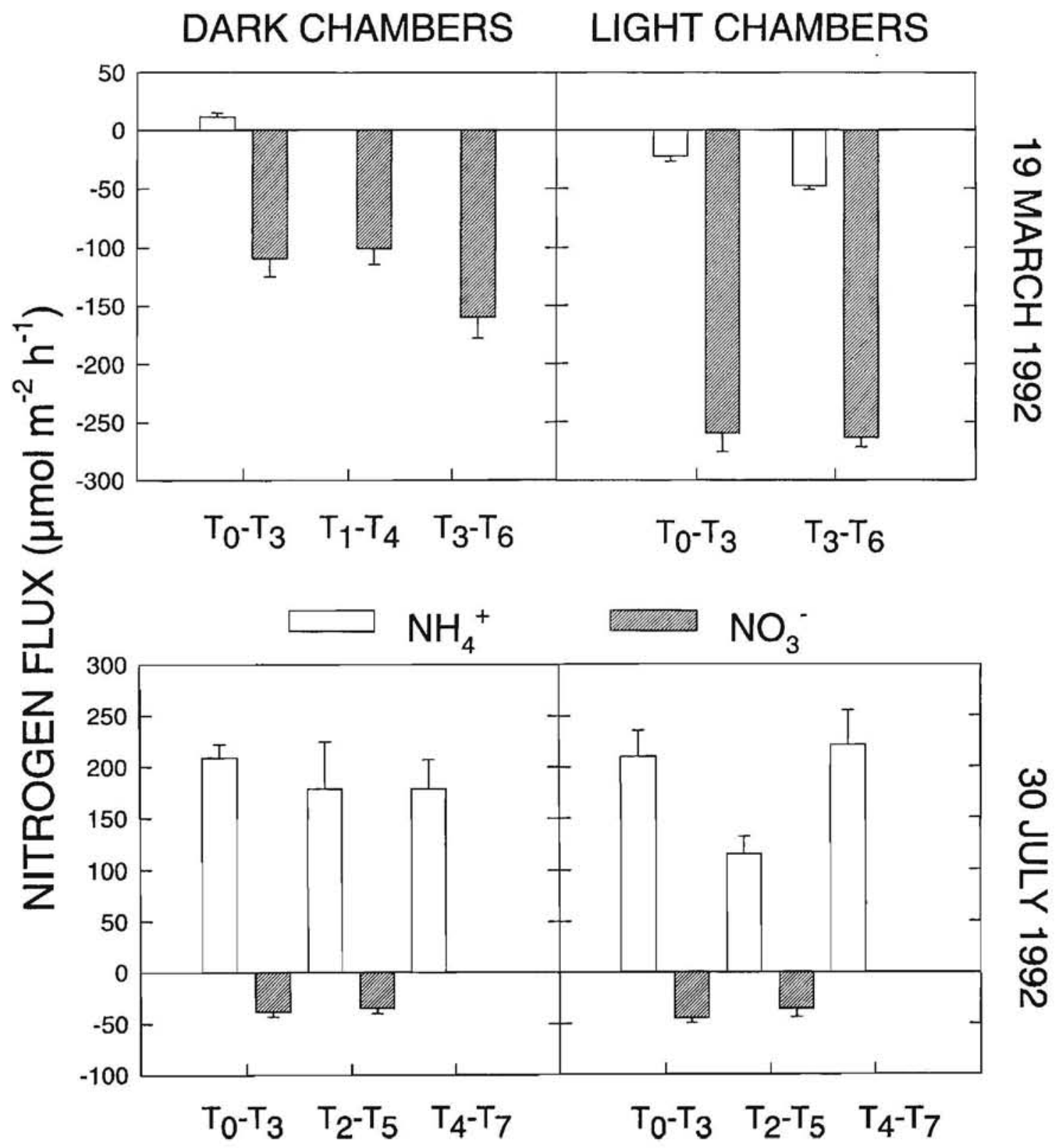

Figure 4. - Actual nitrogen $\left(\mathrm{NH}_{4}^{+}\right.$and $\left.\mathrm{NO}_{3}^{-}\right)$fluxes $\left(\mu \mathrm{mol} \cdot \mathrm{m}^{-2} \cdot \mathrm{h}^{-1}\right)$ measured in mini light and dark chambers at different times of the emersion period on 19 March and 30 July 1992.

even though meiofauna and macrofauna did not exhibit their peak abundance in late winter.

In July, the value of the $\mathrm{J}_{0} / \mathrm{J}_{\mathrm{D}}$ ratio for ammonia was about 3 (Table 1) which is very close to that found by Elderfield et al. (1981) (ratio of 1.7 to 3.4), Hopkinson (1987) (ratio in the range 2.2-10.5) and Grenz et al. (1991) (ratio of 5). These authors attribute it to bioturbation which enhances ammonia release from the sediment. However, this can also indicate excretion by the benthos (Williams et al., 1985). Overall, the mean potential release rate of $\mathrm{NH}_{4}^{+}$in summer (around $185 \mu \mathrm{mol} \cdot \mathrm{m}^{-2} \cdot \mathrm{h}^{-1}$ ) was much higher than in winter (around $10 \mu \mathrm{mol} . \mathrm{m}^{-2} \cdot \mathrm{h}^{-1}$ at the beginning of low tide). Concerning nitrate, the measured uptake rate (about $\left.35 \mu \mathrm{mol} \cdot \mathrm{m}^{-2} \cdot \mathrm{h}^{-1}\right)$ was lower than in winter $(100$ $\left.160 \mu \mathrm{mol} \cdot \mathrm{m}^{-2} \cdot \mathrm{h}^{-1}\right)$, but the $\mathrm{J}_{0} / \mathrm{J}_{\mathrm{D}}$ ratio was similar (7-10), thus indicating the same processes (Table 1). However, parallel measurements showed that there was no nitrification, and denitrification was low and only due to nitrate uptake from the overlying water (Feuillet-Girard et al., unpublished).

Measured phosphate flux in July was 17 to 48fold higher-than diffusive fluxes (Table 1) and was in the same order of magnitude than those found 
by Grenz et al., 1991. Although bioturbation can greatly increase the $\mathrm{J}_{0} / \mathrm{J}_{\mathrm{D}}$ ratio (Clavero et al., 1992, 1994), our ratio is out of the range reported by these authors. So bioturbation was very likely not the only process responsible for the enhancement of phosphate release from the sediment. The redox conditions (in the first centimetre of the sediment) during summer (Eh $<250 \mathrm{mV}$ vs. about $400 \mathrm{mV}$ in March, and the high sediment oxygen demand in the range 42$46 \mu \mathrm{mol} \cdot \mathrm{m}^{-2} \cdot \mathrm{h}^{-1}$ vs. $13-20 \mu \mathrm{mol} \cdot \mathrm{m}^{-2} \cdot \mathrm{h}^{-1}$ in March; Gouleau et al., 1994) could have led to phosphate release because of the reduction of ferric oxides and hydroxides (Patrick and Khalid, 1974). Moreover, sediment bacteria can also release phosphate under certain redox conditions (Matejka et al., 1992).

As for diffusive fluxes, measured fluxes of silica were 5 to 10 times higher in July than in March (Table 1). Although the $\mathrm{J}_{0} / \mathrm{J}_{\mathrm{D}}$ ratio for ammonia increased from March to July, presumably due to bioturbation and excretion, the $\mathrm{J}_{(0)} / \mathrm{J}_{\mathrm{D}}$ ) ratio for silica remained unchanged. This discrepancy could be due to differences in the kinetics of mineralization of these two nutrients (Callender and Hammond, 1982). The bioturbation, particularly irrigation by tube-dwellers, can enhance both the mineralization rate and the transport of silica, whercas it only affects the transport of ammonia. It is thus possible that the higher dissolution rate of biogenic silica in July than in March, due to a higher temperature and a more rapid removal of silica from pore-water by bioturbation, increased $\mathrm{J}_{D}$ in the same proportion than $\mathrm{J}_{0}$ so that their ratio remained unchanged.

\section{Hourly variability of measured fluxes in dark and light mini-chambers}

The differences between fluxes measured at different times of the emersion periods, in dark chambers as well as in light chambers, show the effect of the emersion period, and implies that such fluxes are different from actual fluxes occurring during high tide. The difference between light and dark fluxes also show that the emersion period enhances the photosynthetic activity of microphytobenthos which modifies significantly the measured fluxes. From this observation it is then possible to analyse the effect of microphytobenthos on nutrient fluxes. For instance, in July, the decrease of $\mathrm{NH}_{4}^{+}$flux from the sediment to the water in light chambers coincided with the highest photosynthetic rate of benthic microalgae (Blanchard and Cariou-Le Gall, 1994).

Overall, by comparing March and July measurements, we can speculate that microphytobenthos prefers $\mathrm{NH}_{4}^{+}$to $\mathrm{NO}_{3}^{-}$as a nitrogen supply, as is usual in microalgae (McCarthy, 1981), because nitrate was not assimilated in July while ammonia was abundant (Fig. 4). On the other hand, in March, nitrate was consumed because of the apparent limitation of ammonia. An important point to be noted is the fact that the assimilated $\mathrm{NH}_{4}^{+}$and $\mathrm{NO}_{3}^{-}$by microphytobenthos in March was supplied by the water column. This suggests that nitrogen was not readily available in the sediment (high dark uptake of nitrate and very low ammonia dark release) or that the diffusion rate of nitrogen within the sediment was so slow that it was easier for benthic microalgae to take up nitrogen from above in the water. Thus, there was a potential nitrogen limitation in the sediment for microphytobenthos. Moreover, these measurements represent potential values since we measured a flux at a time where it cannot occur because of the absence of water during low tide. In the actual conditions, there is no supply of nitrogen from the water column and microphytobenthos has to cope with the available nitrogen in pore water. As a result, there could be a nitrogen limitation in winter during low tide when microphytobenthos photosynthesis is highest, unless benthic microalgae are able to constitute an intracellular pool of nitrogen during dark periods of high tides.

No significant difference was observed between dark and light chambers concerning phosphate and silica.

\section{CONCLUSION}

On the mudflats of Marennes-Oléron Bay, there were potentially an uptake of nitrate and phosphate during winter and a release of ammonia and phosphate during summer. Phosphate uptake or release was primarily due to the redox potential of the sediment while nitrate uptake seemed to be due to the coupling of nitrification and denitrification, that is a net loss of nitrogen from the sediment. As this occurred when nitrate concentration was low in the sediment and high in the water column, there could be a regulation of nitrogen concentration in the water column by the sediment. This is an important point because nitrogen is thought to be a limiting factor of primary production in Marennes-Oléron Bay. Undoubtedly, more work has to be done on this topic, all the more that the contribution of benthic regeneration on mudflats to total nutrient supply of Marennes-Oléron Bay is not known yet, and its relative importance compared to the nutrient input by the River Charente and other input points from salt marshes needs to be established to understand the dynamics of primary production.

It also turned out that the emersion period could have a significant effect on fluxes since nitrate uptake on the mudflat was significantly higher at the end of emersion than at the beginning in March. This result calls for further insights in nitrogen processes.

Finally, it appeared that microphytobenthos had a greater affinity for ammonia but assimilated nitrate in winter when ammonia was not available. A nitrogen-limitation could have occurred during emersion in winter and benthic regeneration was the main source of ammonia in summer since $\mathrm{NH}_{4}^{+}$ concentration was always low in the water column. The photosynthetic activity of microphytobenthos also significantly changed the nutrient fluxes at the surface of the sediment.

Aquat. Living Resour., Vol. 10, n $1-1997$ 


\section{Acknowledgements}

This work was supported by the Commission of the European Communities (contract FAR AQ 2500) and has been presented in the GIP Symposium on: "Relations continent - zones côtières : dynamique des apports et conséquences biologiques, à travers l'exemple de la Charente"; La Rochelle (France) 13-15 September 1994.

\section{REFERENCES}

Berner R.A. 1976. Inclusion of adsorption in the modeling of early diagenesis. Earth Planet. Sci. Lett. 29, 333-340.

Billen G. 1978. A budget of nitrogen recycling in North Sea sediments off the Belgian coast. Estuar. Coast. Mar. Sci. 7, 127-146.

Blanchard G., V. Cariou-Le Gall 1994. Photosynthetic characteristics of microphytobenthos in Marennes-Oléron Bay, France: preliminary results. J. Exp. Mar. Biol. Ecol. $182,1-14$.

Boynton W.R., W.M. Kemp., C.G. Osborne 1980. Nutrient fluxes across the sediment-water interface in the turbid zone of a coastal plain estuary. In: Estuarine perspectives. V.S. Kennedy ed. Academic Press, New York, 93-109.

Callender E., D.E. Hammond 1982. Nutrient exchange across the sediment-water interface in the Potomac river estuary. Estuar. Coast. Shelf Sci. 15, 395-413.

Clavero V., J.A. Fernandez, F.X. Niell 1992. Bioturbation by Nereis sp. and its effects on the phosphate flux across the sediment-water interface in the Palmones river estuary. Hydrobiologia 235/236, 387-392.

Clavero V., F.X. Niell, J.A. Fernandez 1994. A laboratory study to quantify the influence of Nereis diversicolor O.F.Müller in the exchange of phosphate between sediment and water. J. Exp. Mar. Biol. Ecol. 176, 257-267.

Elderfield R., R. McCaffrey, N. Luedtke, M. Bender, V. Truesdale 1981. Chemical diagenesis in Narragansett Bay sediments. Am. J. Sci. 281, 1021-1055.

Feuillet-Girard M., M. Héral, J.-M. Sornin, J.-M. Deslous Paoli, J.-M. Robert, F. Mornet, D. Razet 1988. Éléments azotés de la colonne d'eau et de l'interface eau-sédiment du bassin de Marennes-Oléron: influence des cultures d'huîtres. Aquat. Living Resour. 1, 251-265.

Gouleau D., G. Blanchard, V. Cariou-Le Gall 1994. Production potentielle et consommation d'oxygène sur une vasière intertidale au cours d'une émersion. Vie et Milieu 44, 109-115.

Grenz C., T. Moutin, B. Picot, H. Massé 1991. Comparaison de deux méthodes de mesure de flux de nutriments a l'interface eau-sédiment: méthode des peepers et méthode des chambres benthiques. C.R. Acad. Sci., Paris, Sér. III, 313, 239-244.

Hopkinson C.S. Jr. 1987. Nutrient regeneration in shallowwater sediments of the estuarine plume region of the nearshore Georgia Bight, U.S.A. Mar. Biol. 94, 127-142.

Jenkins M.C., W.M. Kemp 1984. The coupling of nitrification and denitrification in two estuarine sediments. Limnol. Oceanogr. 29, 609-619.

Kemp W.M., P. Sampou, J. Caffrey, M. Mayer, K. Henriksen, W.R. Boynton 1990. Ammonia recycling versus denitrification in Chesapeake Bay sediments. Limnol. Oceanogr. 35, 1545-1563.
Koike I., J. Sorensen 1988. Nitrate reduction and denitrification in marine sediments. In: Nitrogen cycling in coastal marine environments. T.H. Blackburn, J. Sorensen eds. Wiley, 251-274.

Krom M.D., R.A. Berner 1980. The diffusion coefficients of sulfate, ammonia, and phosphate ions in anoxic marine sediments. Limnol. Oceanogr. 25, 327-337.

Lerat Y., P. Lasserre., P. Le Corre 1990. Seasonal changes in pore water concentrations of nutrients and their diffusives fluxes at the sediment-water interface. J. Exp. Mar. Biol. Ecol. 135, 135-160.

Li Y.H., S. Gregory 1974. Diffusion of ions in sea water and deep sea sediments. Geochim. Cosmochim. Acta 38, 703-714.

Manheim F.T. 1970. The diffusion of ions in unconsolidated sediments. Earth Planet. Sci. Lett. 9, 307-309.

Matejka G., G. Feuillade, I. Heulot, P. Lemehaute, M. Mazet 1992. Les échanges de phosphore à l'interface eau-sédiments. Tribune de l'eau 556, 19-25.

McCarthy J.J. 1981. Uptake of major nutrients by estuarine plants. In: Estuaries and nutrients. B.J. Nielson, L.E. Cronin eds. Humana Press, Clifton, New Jersey, USA, 139-163.

Nilsson P., B. Jönsson, I. Lindström Swanberg, K. Sundbäck 1991. Response of a marine shallow-water sediment system to an increased load of inorganic nutrients. Mar. Ecol. Prog. Ser. 71, 275-290.

Nixon S.W., C. Oviatt, S. Hale 1976. Nitrogen regeneration and the metabolism of coastal marine bottom communities. In: The role of terrestrial and aquatic organisms in decomposition processes. J. Anderson, A. Macfadyen eds. Blackwell Scientific, London, 269-283.

Nixon S.W. 1981. Remineralization and nutrient cycling in coastal marine ecosystems. In: Estuaries and nutrients. B.J. Nielson, L.E. Cronin eds. Humana Press, Clifton, New Jersey, USA, 111-138.

Nowicki B.L., S.W. Nixon 1985. Benthic nutrient remineralization in a coastal lagoon ecosystem. Estuaries 8 , 182-190.

Patrick W.H., R.A. Khalid 1974. Phosphate release and sorption by soils and sediments: effect of aerobic and anaerobic conditions. Science 186, 53-55.

Peterson D.H. 1979. Sources and sinks of biologically reactive oxygen, carbon, nitrogen and silica in northern San Francisco Bay. In: San Francisco Bay, the urbanized estuary. T.J. Conomos ed. American Association for the advancement of Science, San Francisco, 175-193.

Riera P., P. Richard 1996. Isotopic determination of food sources of Crassostrea gigas along a trophic gradient in the estuarine bay of Marennes-Oléron. Estuar. Coast. Shelf Sci. 42, 347-360. 
Rizzo W.M. 1990. Nutrient exchanges between the water column and a subtidal benthic microalgal community. Estuaries 13, 219-226.

Rizzo W.M., G.J. Lackey, R.R. Christian 1992. Significance of euphotic, stibtidal sediments to oxygen and nutriert cycling in a temperate estuary. Mar. Ecol. Prog. Ser. OJ, 51-61.

Rutgers van der Loeff M.M., L.G. Anderson, P.O.J. Hall, A. Iverfeldt, A.B. Josefson, B. Sundby, F.G. Westerlund 1984. The asphyxiation technique: an approach to distinguishing between molecular diffusion and biologically mediated transport at the sediment-water interface. Limnol. Oceanogr. 2), 675-686.

Seitzinger S.P. 1938. Denitrification in freshwater and coastal marine ecosystems: ecological and geochemical significance. Limnol. Oceanogr. 33, 702-724.
Simon N.S.1938. Nitrogen cycling between sediment and the shallow-water column in the transition zone of the Potomac river and estuary. 1. Nitrate and Ammonia Fluxes. Estuar. Coast. Shelf Sci. 19, 15-25.

Sokal R.R., F.J. Rohlf 1981. Biometry, 2nd ed. W.H. Freeman and Company, New York, 859 p.

Surbäck K.., V. Enoksson, W. Granáli, K. Pettersson 1991. Influence of sublittoral microphytoberthos on the oxygen and nutrient flux between sedimert and water: a laboratory continuous-flow study. Mar. Ecol. Prog. Ser. 7i., 263-279.

Williams S.L., S.M. Yarish, J.P. Gill 1935. Ammonia distributions, production and efflux from backreef sediments. St. Croix, U.S. Virgin Islands. Mar. Ecol. Prog. Ser. 24, 57-64. 